
им. Г.П. Лузина - обособленное подразделение ФБГУН Фредерального исследовательского иентра «Кольский научный иентр

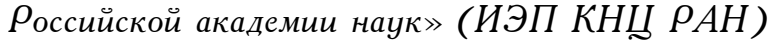
e-mail: bashmakova@iep.kolasc.net.ru

УЛЬЧЕНКО МИХАИЛ ВАСИЛЬЕВИЧ к.э.н., доцент в.н.с. в.н.с., Институт экономических проблем им. Г.П. Лузина обособленное подразделение ФГБУН Федерального исследовательского иентра «Кольский научный иентр e-mail: ulchenko23@rambler.ru

\title{
РАЗВИТИЕ СЕВЕРНОГО МОРСКОГО ПУТИ И ИНФРАСТРУКТУРЫ АРКТИЧЕСКОЙ ТРАНСПОРТНОЙ СИСТЕМЫ
}

Аннотауия. Џель работы. Цель работы заключается в анализе современного этапа развития Северного морского пути и инфраструктуры арктической транспортной системы. Метод или методология проведения работы. При написании настоящей статьи авторами были использованы инструменты, современные методы и формы экономического анализа. Основой для проведения исследования послужили научные статьи, нормативноправовые акты, а также официальные статистические данные. Проведенный анализ позволил сделать вывод о том, что, как и любая другая страна, обладающлая прямым выходом к Северному Ледовитому океану, Российская ФФедерация должна иметь развитую транспортную систему в Арктической зоне. Результаты. Слабая развитость наземной

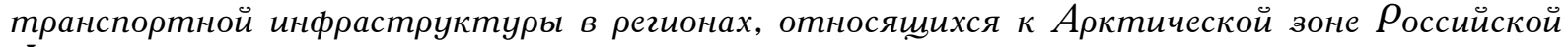
Федерации, а также дороговизна альтернативных вариантов - воздушных и речных перевозок, позволяет утверждать, что морской транспорт является единственно приемлемым вариантом для транспортировки грузов, обеспечения жизнедеятельности населения и промышленных производств. Именно поэтому обеспечение морской транспортировки в регионах Арктической зоны Российской Федераиии имеет приоритетное стратегическое значение: - реализации планов развития инфраструктуры СМП обеспечит круглогодичную работу арктической магистрали в период 2030-2035 годов и рост грузооборота СМП до 80 млн $m$ к 2024 году с дальнейшим увеличением до 110-120 млн т к 2030 году и до 160 млн т к 2035 году; - наиболее эффективным для транспортной системы Арктики является создание спещиализированной флотилии, используемой только на трассе СМП при доставке грузов до замыкающих СМП хабов в Мурманске и Петропавловске-Камчатском, откуда они могут развозиться уже любыми судами, в том числе высокой грузоподъемности; - при соответствующем подходе услуги по транспортировке грузов по СМП, наряду с доходами от реализаиии нефтегазовой продукиии, могут превратиться в высокодоходную статью экспорта в российской Арктике. Выводы. На основании проведенного анализа состояния Северного морского пути и инфраструктуры арктической транспортной системы был сделан вывод о том, что широкомаситабное освоение ресурсов, в том числе и на шельфе арктических морей, а также устойчивое соииаль-

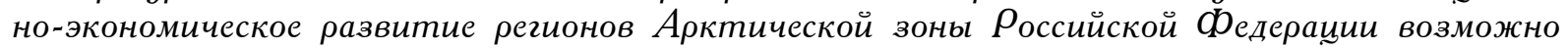
только при наличии развитой логистики.

Ключевые слова: транспорт, Арктика, грузооборот, Северный морской путь.

\footnotetext{
${ }^{1}$ Исследование выполнено в рамках Программы Президиума РАН «Социально-гуманитарные аспекты устойчивого развития и обеспечения стратегического прорыва России» (подпрограмма «Пространственная реструктуризация России с учетом геополитических, социально-экономических и геоэкологических вызовов»).
} 
BASHMAKOVA ELENA PETROVNA

Ph. D., associate Professor, $V . n$. s., Institute of economic problems G. $\rho$. Luzin - a separate division of the Federal state budgetary institution research center" Kola scientific center Russian Academy of Sciences" (IE $\rho$ KNC RAS) e-mail: bashmakova@iep.kolasc.net.ru

ULCHENKO MIKHAIL VASILIEVICH

$\rho_{h} . D$. in Economics, associate $\rho_{\text {rofessor, Institute of economic problems named }}$ after G. $P$. Luzin - separate division of the Federal research center Kola research center of the Russian Academy of Sciences (IEP KSC RAS) e-mail: ulchenko23@rambler.ru

\title{
DEVELOPMENT OF THE NORTHERN SEA ROUTE AND INFRASTRUCTURE ARCTIC TRANSPORT SYSTEM
}

\begin{abstract}
Purpose of work. The purpose of this work is to analyze the current stage of development of the Northern sea route and the infrastructure of the Arctic transoort system. Method or methodology of the work. When writing this article, the authors used tools, modern methods and forms of economic analysis. The research was based on scientific articles, legal acts, and official statistics. The analysis made it possible to conclude that, like any other country with direct access to the Arctic ocean, the Russian Federation should have a developed transport system in the Arctic zone. Results. The poor development of land transport infrastructure in the regions belonging to the Arctic zone of the Russian Federation, as well as the high cost of alternative options - air and river transport, suggests that sea transport is the only acceptable option for transporting goods, ensuring the life of the population and industrial production. That is why ensuring sea transportation in the regions of the Arctic zone of the Russian Federation is of priority strategic importance: - implementation the NSR infrastructure development plans will ensure yearround operation of the Arctic highway in the period 2030-2035 and increase the NSR cargo turnover to 80 million tons by 2024, with further increases to 110-120 million tons by 2030 and 160 million tons by 2035; - the most effective for the Arctic transport system is the creation of a specialized flotilla that is used only on the NSR route when delivering cargo to the

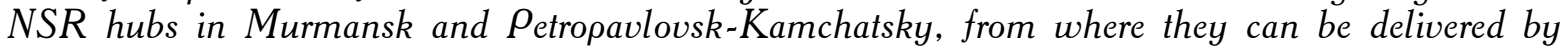
any vessels, including high-capacity vessels; - with the appropriate approach, cargo transportation services along the NSR, along with revenues from the sale of oil and gas products, can become a highly profitable export item in the Russian Arctic. Conclusions. Based on the analysis of the state of the Northern sea route and the infrastructure of the Arctic transport system, it was concluded that large-scale development of resources, including on the shelf of the Arctic seas, as well as sustainable socio-economic development of the regions of the Arctic zone of the Russian Federation is possible only if there is a developed logistics.
\end{abstract}

Keywords: transport, the Arctic, the turnover of the Northern sea route.

Введение. Согласно «Стратегии пространственного развития РФ до 2025 года» [1], основой для обеспечения устойчивых транспортных связей между субъектами Российской Федерации, перспективными центрами экономического роста, а также для внешнеэкономических связей является опорная транспортная сеть Российской Федерации - совокупность магистральных путей сообщения и транспортных узлов. Для обеспечения ликвидации инфраструктурных ограничений федерального значения и повышения доступности и качества магистральной транспортной, энергетической и информационно-телекоммуникационной инфраструктуры предлагается ряд мер, большая часть которых присутствует в Мегапроекте.

Мегапроект «Единая Евразия: Трансъевразийский пояс RAZVITIE - Интегральная евразийская транспортная система (Единая Евразия: ТЕПР-ИЕТС)» [5], который должен обеспечить связанность территорий и их активное развитие. Основной идеей Мегапроекта является создание условий для эффективного комплексного освоения Сибири, Дальнего Востока и Арктики на базе создания двух пространственных транспортно-логистических коридоров между Евро- 
пой и Азией с опорой на высокоскоростной железнодорожный комплекс и Северный морской путь, включающие в себя несколько стратегических транспортно-логистических узлов (хабов) в Уральском, Сибирском и Дальневосточном федеральных округах и Арктике, объединенных между собой в единую транспортно-логистическую систему.

Принят или находится в процессе согласования еще ряд документов, в приоритеты которых входят и транспортные направления. К таким документам относятся: проект «Стратегия развития Арктической зоны РФ до 2035 года» [9], проект «Развитие Северного морского пути до 2035 года» [4] и «Комплексный план модернизации и расширения магистральной инфраструктуры на период до 2024 года» [6].

Включение всей арктической транспортной системы и Северного морского пути в эти стратегические документы означает их глобальную, национальную и региональную значимость в обеспечении экономических интересов и национальной безопасности России в Арктике.

С этих позиций развитие и инфраструктурное обустройство арктической транспортной системы и Северного морского пути как главнейшей транспортной магистрали Арктики является крайне актуальной экономической задачей. Именно транспортная система Российской Арктики должна обеспечить промышленное и социальное развитие арктических территорий, так как транспорт - основа реализации всех инвестиционных и инновационных действующих и прогнозируемых проектов освоения топливно-энергетических, горнопромышленных и других ресурсов на территории арктических регионов.

Методы и результаты исследования. Перспективы развития транспорта и транспортной инфраструктуры в Арктической зоне Российской Федерации связаны с возможностью освоения значительных запасов биологических и минерально-сырьевых ресурсов $[13,14]$.

В настоящее время транспортная инфраструктура в Российской Арктике развита слабо, отличается низкой плотностью дорог с твердым покрытием и железнодорожных путей сообщения. При этом использование речных и авиаперевозок осложняется из-за их дороговизны. В таких условиях морские грузоперевозки являются безальтернативным методом доставки грузов до населения и промышленных производств. Именно поэтому морской транспорт имеет приоритетное стратегическое значение для Арктической зоны Российской Федерации [15].

Согласно «Стратегии развития Арктики до 2035 года», ключевым направлением становится развитие и модернизация всей транспортной системы. Бесперебойное транспортное сообщение становится ключом к широкомасштабному освоению арктических ресурсов и обеспечению социально-экономического роста арктических регионов и Арктической зоны Российской Федерации в целом [4].

Основной морской транспортной магистралью Арктики является Северный морской путь, который относительно условно можно подразделить на:

1. Так называемый западный сектор Арктики, который простирается от города Мурманска до Дудинки. Обслуживание данного сектора осуществляется ледоколами Росатомфлота.

2. Восточный сектор, располагающийся от Чукотки до Дудинки. Обслуживание данного сектора осуществляется ледоколами Дальневосточного морского пароходства.

В настоящее время на самой трассе Северного морского пути располагается более пятидесяти портов - Мурманск, Архангельск, Нарьян-Мар, Варандей, Сабетта и ряд других.

Все порты Северного морского пути нуждаются в срочной модернизации - строительство или ремонт устаревших причальных сооружений, приобретение и установка навигационных систем, отвечающих современным требованиям, проведение работ по дноуглублению, что позволит принимать современные, сверхкрупные суда различных классов и др. [12].

Особую актуальность приобретают задачи более детального изучения акватории Северного морского пути для определения новых глубоководных путей, необходимых для проведения крупнотоннажных судов, в том числе новых атомных ледоколов.

Необходимость проведения дополнительного изучения обусловлена тем, что часть портов имеет лимитированные глубины: Диксон -8 метров, Певек - 9 метров, Тикси - 4 метра, Амдерма - менее 2 метров [10]. При этом современные газовозы ледового класса Arc-7 имеют осадку 12 метров. Подготовка этих портов для обслуживания крупнотоннажных судов потребует дополнительных дноуглубительных работ.

На решение инфраструктурных проблем СМП ориентирован новый федеральный проект 
«Северный морской путь» [8]. Основной целью проекта является увеличение грузопотока на трассе СМП до отметки в 75-80 млн тонн в ближайшие 5 лет. Он входит в «Комплексный план модернизации и расширения магистральной инфраструктуры на период до 2024 года», разработанный в соответствии с Указом Президента России от 7 мая 2018 года № 204 «О национальных целях и стратегических задачах развития Российской Федерации на период до 2024 года».

Общую стоимость реализации проекта СМП Минтранс [7] оценивает в 734,9 млрд руб., из них 273,6 млрд руб. будет выделено из бюджета. Прокладка Северного широтного хода от Обской губы до Коротчаево обойдется в 152 млрд руб. На строительство СПГ-терминала «Утренний» в порту «Сабетта» для второго завода НОВАТЭКа «Арктик СПГ-2» мощностью 19,8 млн т предусмотрено 112,25 млрд руб. (81,9 млрд руб. из бюджета, 30,35 млрд руб. - от частных инвесторов).

На трассах Северного морского пути (СМП) запланирована обширная программа строительства и реконструкции портов. Но реальное строительство в 2017-2019 годах велось только в порту «Сабетта» на выходе из Обской губы и на терминале, расположенном на мысе Каменный, где осуществляется перевалка нефти с «Новопортовского месторождения», напротив места слияния Обской и Тазовской губ.

В стадии разработки находятся проекты реконструкции порта Нарьян-Мар, порта Индига, строительства нефтяного терминала на мысе Таналау в устье реки Енисей.

В стадии предпроектной разработки находятся проекты строительства глубоководного района порта Архангельск, терминала для перевалки СПГ с Салмановского и Геофизического месторождений на восточном Гыданском берегу Обской губы, угольного терминала в Енисейском заливе на мысе Чайка, морского терминала в Оленекском заливе моря Лаптевых, угольного терминала в порту Беринговский в лагуне Аринай.

При этом в среднесрочной перспективе, до 2024 года, в оставшихся портах Северного морского порта, таких как Анадырь, Эгвекитон, Хатанга, Нарьян-Мар, Игарка, Онега, Мезень, Провидения, Тикси, реализация значимых инвестиционных проектов не планируется. Тем не менее перечисленные порты являются важной составляющей СМП, и для обеспечения безопасности прохождения всей трассы должны получить соответствующую государственную поддержку.

С целью обеспечения безопасности движения на трассе СМП необходимо восстанавливать аварийно-спасательные службы. В настоящее время вдоль всей трассы дежурство несут более восемнадцати тысяч спасателей МЧС, которые работают в 5 спасательных центрах: Дудинке, Нарьян-Маре, Мурманске, Вытегре и Архангельске. В планах строительство еще шести аварийно-спасательных комплексов в Анадыре, Воркуте, Певеке, Надыме, Провидении и Тикси. Предполагается, что сотрудники перечисленных центров смогут оперативно реагировать на любую внештатную ситуацию, возникающую не только на трассе СМП, но и вообще в этой части арктической зоны. Центры сделают высокомобильными: оснастят авиационными средствами, вездеходами, универсальным аварийно-спасательным оборудованием и плавсредствами.

Безусловно, увеличение грузопотока на трассе Северного морского пути за счет освоения арктических месторождений будет способствовать привлечению новых инвестиций и повысит интерес местных властей к магистрали. Очевидно, что использование трассы не ограничится только вывозом извлекаемых ресурсов, появится возможность осуществлять так называемый северный завоз - товары, необходимые для обеспечения жизнедеятельности местного населения и функционирующих предприятий [3].

Особое внимание необходимо обратить на развитие ключевых портов - ПетропавловскКамчатский и Мурманск, которые в ближайшей перспективе должны стать так называемыми портами-хабами, что будет способствовать увеличению объемов транзитных грузоперевозок, в том числе и контейнерных, а также общему экономическому развитию арктических территорий. Финансирование создания и развития обозначенных транспортных узлов должно осуществляться за счет средств всех заинтересованных в этом сторон - частного бизнеса, а также федеральных и региональных властей.

Ориентировочный прогноз строительства и реконструкции морских портов на трассе СМП на 2020-2030 и 2050 годы представлен в таблице 1. 
БАНМАКОВА Е.П., УЛЬЧЕНКО М.В.

РАЗВИТИЕ СЕВЕРНОГО МОРСКОГО ПУТИ И ИНФРАСТРУКТУРЫ АРКТИЧЕСКОЙ ТРАНСПОРТНОЙ СИСТЕМЫ

Таблица 1

\section{Строительство и реконструкция морских портов на трассе СМП на 2020-2024 и 2030-2025 годы [5, 6]}

\begin{tabular}{|c|c|}
\hline Порт, регион & Краткая характеристика и обоснование необходимости мероприятия \\
\hline \multicolumn{2}{|r|}{ Мероприятия 1-го этапа (2020-2024 годы) } \\
\hline Диксон & Строительство угольного терминала в районе мыса Чайка с грузооборотом 10 млн т в год. \\
\hline $\begin{array}{l}\text { Нефтяной терминал } \\
\text { Таналау в устье реки } \\
\text { Енисей }\end{array}$ & $\begin{array}{l}\text { Строительство морского порта для перевалки нефти мощностью до } 5 \text { млн т в год и грузов, } \\
\text { необходимых для обустройства и эксплуатации нефтегазовых Пайяхского и Север- } \\
\text { Пайяхского месторождений. }\end{array}$ \\
\hline Мурманск & $\begin{array}{l}\text { В рамках первого этапа планируется строительство терминала Лавна для приема угля, так } \\
\text { называемого экологического терминала для отходов судов общей мощностью тридцать } \\
\text { пять тысяч м }{ }^{3} \text { Арктической гавани. Кроме того, предполагается реконструкция пирса, } \\
\text { двух районов грузового порта, а также самого здания морского вокзала. В результате } \\
\text { увеличение грузооборота должно составить не менее } 18-20 \text { т. }\end{array}$ \\
\hline $\begin{array}{l}\text { Сабетта, } \\
\text { Ямало-Ненецкий АО }\end{array}$ & $\begin{array}{l}\text { Строительство: подходного канала и морского порта в районе пос. Сабетта мощностью } \\
16,5 \text { млн т; морской порт в районе пос. Мыс Каменный мощностью до } 8,5 \text { млн т в год для } \\
\text { отгрузки нефти Новопортовского месторождения; морской порт СПГ и стабильного газо- } \\
\text { вого конденсата терминала «Ворота Арктики» } 21,6 \text { млн т в год. }\end{array}$ \\
\hline Певек, Чукотский АО & $\begin{array}{l}\text { Расширение территории морского порта Певек для освоения Баимской рудной зоны и } \\
\text { увеличения объема грузов до } 2 \text { млн т в год к } 2026 \text { году. }\end{array}$ \\
\hline $\begin{array}{l}\text { Петропавловск- } \\
\text { Камчатский }\end{array}$ & $\begin{array}{l}\text { Привлечение транзитных грузов, строительство контейнерного терминала, рост грузового } \\
\text { потока может составить 7-10 млн т ежегодно к } 2025 \text { году. }\end{array}$ \\
\hline \multicolumn{2}{|r|}{ Мероприятия 2-го этапа (2030-2035 годы) } \\
\hline Архангельск & $\begin{array}{l}\text { Реконструкция и строительство объектов порта, создание проходной глубины на канале } \\
12 \text { м для пропуска судов с осадкой до } 10,5 \text { м, обеспечение безопасности мореплавания, } \\
\text { повышение пропускной способности причалов, реконструкция терминалов и акватории } \\
\text { для обслуживания рыбопромыслового флота, строительство нового грузового района и } \\
\text { реконструкция подходного канала, глубоководного района «Северный» в северной части } \\
\text { порта для перевалки угля, минеральных удобрений, контейнеров мощностью } 28 \text { млн т в } \\
\text { год. }\end{array}$ \\
\hline $\begin{array}{l}\text { Анадырь, } \\
\text { Чукотский АO }\end{array}$ & $\begin{array}{l}\text { Планируется строительство нового причала, который будет расположен в поселке Уголь- } \\
\text { ные Копи на берегу Анадырского лимана. Ориентировочная пропускная способность } \\
\text { паромно-пассажирского причала составит от } 20 \text { до } 25 \text { тыс. человек. Кроме того, в пла- } \\
\text { нах - реконструкция действующего морского порта. }\end{array}$ \\
\hline $\begin{array}{l}\text { Беринговский, } \\
\text { Чукотский АО }\end{array}$ & $\begin{array}{l}\text { В лагуне Аринай планируется строительство нового угольного терминала, предполагае- } \\
\text { мая мощность - } 15 \text { млн т. }\end{array}$ \\
\hline $\begin{array}{l}\text { Диксон, } \\
\text { Красноярский край }\end{array}$ & $\begin{array}{l}\text { Для обеспечения деятельности гидрографических и аварийно-спасательных судов, при- } \\
\text { званных заниматься бункеровкой, ремонтом, пополнением запасов, а также ликвидацией } \\
\text { разливов нефти, планируется модернизация имеющейся инфраструктуры - портовых } \\
\text { сооружений и причалов. }\end{array}$ \\
\hline Мурманск & $\begin{array}{l}\text { Строительство новых, а также модернизация уже существующих терминалов. Планируе- } \\
\text { мая мощность новых терминалов составляет } 35 \text { млн т. }\end{array}$ \\
\hline $\begin{array}{l}\text { Морской порт Тери- } \\
\text { берка, Мурманская } \\
\text { область }\end{array}$ & $\begin{array}{l}\text { Для перевалки сжиженного природного газа в поселке Териберка планируется строитель- } \\
\text { ство порта с новым терминалом общей мощностью } 30 \text { млн т. }\end{array}$ \\
\hline $\begin{array}{l}\text { Певек } \\
\text { Чукотский АO }\end{array}$ & $\begin{array}{l}\text { Для обеспечения деятельности гидрографических и аварийно-спасательных судов, при- } \\
\text { званных заниматься бункеровкой, ремонтом, пополнением запасов, а также ликвидацией } \\
\text { разливов нефти, планируется модернизация имеющейся инфраструктуры - портовых } \\
\text { сооружений и причалов. }\end{array}$ \\
\hline $\begin{array}{l}\text { Тикси, } \\
\text { Республика Саха } \\
\text { (Якутия) }\end{array}$ & $\begin{array}{l}\text { Для обеспечения деятельности гидрографических и аварийно-спасательных судов, при- } \\
\text { званных заниматься бункеровкой, ремонтом, пополнением запасов, а также ликвидацией } \\
\text { разливов нефти, планируется модернизация имеющейся инфраструктуры - портовых } \\
\text { сооружений и причалов. }\end{array}$ \\
\hline $\begin{array}{l}\text { Беломорск, Республика } \\
\text { Карелия }\end{array}$ & $\begin{array}{l}\text { Для приема судов дедвейтом до } 70 \text { т (на первоначальном этапе до } 30 \text { тыс. т) планируется } \\
\text { строительство нового морского порта. Современный порт будет обладать двумя грузовы- } \\
\text { ми районами, 1-й район - универсальный комплекс мощностью до одного млн тонн, 2-й - } \\
\text { угольный комплекс, мощность которого будет достигать восьми млн т. }\end{array}$ \\
\hline \multicolumn{2}{|c|}{$\begin{array}{l}\text { В перспективе до } 2050 \text { года (3-й этап) будет проводиться реконструкция и модернизация следующих портов: Ам- } \\
\text { дерма - Ненецкий АО; Варандей - Ненецкий АО; Витино - Белое море, Мурманская область; Игарка - Краснояр- } \\
\text { ский край; Кандалакша - Мурманская область; Новый порт - ЯНАО; Провидения - Чукотский АО; Хатанга - Крас- } \\
\text { ноярский край; Эгвекинот - Чукотский АО; Индига и Усть-Кара - Ненецкий АО. }\end{array}$} \\
\hline \multicolumn{2}{|c|}{$\begin{array}{l}\text { В Комплексный план по развитию инфраструктуры до } 2024 \text { года как первоочередные включены четыре объекта: } \\
\text { Диксон, Певек, Терминал Таналау, Мурманский морской порт. }\end{array}$} \\
\hline
\end{tabular}

Источник: https://rg.ru/2019/07/25/sistema-arkticheskih-preferencij-budet-gotova-v-blizhajshie-nedeli.html. 
В соответствии с планами развития инфраструктуры СМП, разработанными «Росатомом» и «Минвостокразвития» [8], круглогодичная работа арктической магистрали возможна в период 2030-2035 годов. К этому времени должно окончательно проясниться, как работает система транспортировки в арктических регионах. По некоторым прогнозам [10], грузооборот СМП, благодаря строящимся атомным ледоколам и намеченному развитию инфраструктуры, увеличится до 92,56 млн т уже к концу 2024 года и к 2030 году достигнет 110-120 млн т в год, к 2035 году - 160 млн т.

Увеличение грузопотоков СМП требует строительства значительного количества транспортных средств. В настоящее время услуги по проводке судов по трассе Северного морского пути предоставляют 3 компании - «Дальневосточное морское пароходство», «Росморпорт», «Мурманское пароходство». ПАО «Норильский Никель» начиная с середины 2000-х годов самостоятельно осуществляет проводку своих судов по всей трассе. В настоящее время компании принадлежат шесть судов ледового класса Arc-7, способных без ледокольного сопровождения преодолевать льды на западном и восточном участках СМП. Ежегодный объем перевозки грузов с помощью морского транспорта превышает отметку в 1,6 млн т. Кроме транспортировки конечного сырья, компания осуществляет доставку социально значимых грузов, необходимых для жителей Норильского района и материалов, которые обеспечивают непрерывный производственный процесс [10].

ПАО «НОВАТЭК» для вывоза сжиженного природного газа, производимого в рамках реализации проекта «Ямал-СПГ», без ледокольной проводки осуществляет круглогодичную навигацию по трассе Северного морского пути. Транспортировка газа осуществляется с помощью новых танкеров-газовозов ледового класса Arc-7 водоизмещением более 140 тыс. т каждый, 5 вспомогательных судов портового флота, а также ледоколов ФГУП «Атомфлот» для гарантированной круглогодичной проводки газовозов в тяжелых ледовых условиях.

Поскольку полностью без ледокольной проводки на СМП не обойтись, продолжается строительство трех суперледоколов «Лидер» с реакторной установкой РИТМ-400 мощностью 315 МВт, с суммарной мощностью на гребных винтах 120 МВт, которые смогут обеспечить круглогодичную проводку судов по СМП при толщине льда до четырех метров. Три «Лидера» должны быть построены в 2028, 2031 и 2033 годах (стоимость ледокола Лидер - 120-127 млрд руб).

В то же время, как считают эксперты компании ПАО «Новатэк» [11], задачу круглогодичной навигации в 2024-2025 годах можно решить без атомного ледокола «Лидер» мощностью 120 МВт. Для этого необходимо наличие пяти серийных атомных ледоколов ЛК-60 и «50 лет Победы». Первые три атомных ледокола ЛК-60 - «Арктика», «Сибирь» и «Урал» - должны быть сданы в 2020, 2021 и 2022 годах соответственно. Кроме того, к 2025 году должны войти в эксплуатацию четвертый и пятый ЛК-60. Они будут иметь новые реакторы РИТМ-200 (тепловая мощность каждого - 175 МВт), суммарную мощность на гребных винтах - 60 МВт [10]. Данные ледоколы будут самыми крупными и мощными на данный момент.

Строительство ледокольного флота должно быть четко синхронизировано с реализацией проекта «Арктик СПГ - 2», а также запуском двух перевалочных пунктов в Мурманске и на Камчатке. Кроме того, до конца 2020 года «Атомфлотом» будет определена возможность продлить срок работы реакторов атомных ледоколов «Ямал», «Таймыр» и «Вайгач» до 2028, 2025 и 2026 годов соответственно. Однако растущий грузопоток СМП ставит вопрос о том, хватит ли ледоколов для обеспечения этого грузопотока, особенно при увеличении поставок СПГ на восток. Очевидным решением может быть привлечение для вспомогательных функций дизельных ледоколов «Росморпорта».

К 2024 году будет построено 4 ледокола на сжиженном природном газе, первый - в 2021 году [6].

Еще одно направление увеличения дополнительных транспортных средств госкомпания «Росатом» [1] рассматривает с позиций формирования условий для развития транзитных контейнерных перевозок. Инвестиции в создание необходимой транзитной инфраструктуры на СМП «Росатом» оценивает в \$7 млрд. Мощность контейнерной линии в «Росатоме» оценивают в 30 млн т в год к 2028 году. Для перевозки целевого объема контейнерных грузов через СМП потребуется арктический флот из 33 коммерческих судов (контейнеровозов), инвести- 
ции в создание которого оцениваются в $\$ 5,8$ млрд.

Для обеспечения бесперебойного судоходства в Арктике необходимо предоставить пользователям СМП интегральную пакетную услугу «Технически, организационно и информационно обеспеченный график движения судна (груза)». При этом нужно ориентироваться на то, что доставка грузов по СМП и транзит через него будет осуществляться «шатлами» ледового класса до хабов в Мурманске и Петропавловске-Камчатском, куда грузы могут доставлять и откуда грузы могут забирать обычными судами без ледового подкрепления любые транспортные компании. Между хабами должны работать суда единого российского оператора, обеспечивающего жесткое исполнение графика и способного осуществлять маневр силами и средствами без формальных согласований и предварительных платежей между участвующими в процессе субструктурами. Только такое единство обеспечит максимальное сокращение издержек и бюрократических процедур за счет отсутствия лишних управляющих звеньев между техническими и исполнительными структурами.

Наиболее эффективным для транспортной системы Арктики является создание специализированной флотилии, используемой только на трассе СМП. Специфика мореплавания по СМП требует использования судов преимущественно ледового класса, которые в сравнении с обычными судами в 2,5-3 раза дороже. Поэтому и эксплуатировать такие суда выгоднее только на трассах СМП или при сравнительно небольшом удалении от этих трасс, чтобы не делать лишней перевалки груза. В остальных случаях разумнее доставлять ими грузы до замыкающих СМП хабов в Мурманске и Петропавловске-Камчатском, откуда они могут развозиться уже любыми судами, в том числе высокой грузоподъемности.

Впрочем в летние месяцы, в период максимальной загрузки СМП, можно привлекать и другие суда, в том числе и под иностранным флагом, так как невыгодно держать собственную флотилию, способную полностью обеспечить трафик через СМП.

Россия как страна, имеющая выход к Северному Ледовитому океану, не может обойтись без развитой транспортной системы Арктической зоны, в том числе без ледового флота. При грамотном подходе морские транспортные услуги могут превратиться в высокодоходную статью экспорта в Арктической зоне наряду с доходами от нефтегазовой отрасли.

Кроме того, планируется обеспечить круглогодичный трафик каботажных и транзитных перевозок по всей акватории СМП, довести число ледоколов до требуемого уровня и завершить формирование «единого мультимодального оператора СМП с полным функционалом сервисов», включая выбор оптимальных маршрутов и условий перевозок с предоставлением услуги «точно в срок». В рамках третьего этапа в 2035-2050 годах планируется создать на базе Севморпути конкурентоспособный международный мультимодальный транспортный коридор, способный обеспечивать любые запросы потребителей транспортно-логистических услуг.

Современное состояние мониторинговых систем и институциональной инфраструктуры информирования о ситуации в Северном Ледовитом океане не обеспечивает актуальные потребности развивающегося транспортного сектора экономики Арктики в плане оперативного получения информации о навигационных и гидрометеорологических условиях судовождения на трансарктических морских трассах.

В федеральном проекте «Северный морской путь» и Комплексном плане на навигационногидрографическое обеспечение судоходства на трассах СМП в 2019-2024 годах заложено 7,44 млрд руб., еще 20,5 млрд руб. планируется потратить на строительство гидрографических и лоцмейстерских судов $[6,8]$.

В федеральном проекте «Развитие СМП до 2035 года» и Комплексном плане предусмотрены меры по обеспечению спутниковой связью, навигационно-гидрографическому и гидрометеорологическому обеспечению судоходства в акватории СМП, по аварийно-спасательному обеспечению судоходства, по строительству морской техники, систем и средств и др.

В Мегапроекте рассматривается возможность создания Российской трансарктической кабельной системы (РОТАКС) по трассе СМП. Предполагаемая сумма затрат оценивалась в пределах \$1 млрд, однако при этом предполагалось устройство многочисленных ответвлений, удорожавших проект.

В настоящее время прорабатываются два варианта прокладки магистральной волоконнооптической линии связи (ВОЛС) от Мурманска до Анадыря - подводный и сухопутный. Стро- 
ительство ВОЛС на СПМ должно обеспечить безопасность мореплавания, надежность транзита и перевозок углеводородного сырья из морских портов на арктическом побережье, северный завоз и деятельность кораблей и судов Военно-морского флота.

Для развития информационной инфраструктуры АТЛС необходимо создание единой сухопутной и подводной сети ВОЛС, развертывание стабильной группировки космических аппаратов связи и навигации на геостационарной и высокоэллиптических орбитах, повышение качества сигнала цифровых радиорелейных станций, комплектация ИИ отечественными элементами.

Выводы. Арктическую транспортную систему и Северный морской путь можно рассматривать как одну из международных транспортно-логистических магистралей, которая не только должна обеспечить промышленное и социальное развитие арктических территорий, но и реализовать функцию включения Арктики в российское и мировое пространство.

Рост грузопотоков и удовлетворение потребности грузоотправителей в ледоколах, услугах навигации и связи, безопасности создает базу для организации круглогодичной деятельности СМП, что является одним из необходимых условий превращения этой магистрали в глобально конкурентоспособный международный транспортный коридор.

В настоящее время и в ближайшее десятилетие объем грузоперевозок по СМП как важнейшей магистрали арктической транспортно-логистической системы будет практически полностью формироваться за счет российских грузоотправителей. Динамичное освоение минерально-сырьевых ресурсов не только обеспечит интенсивный рост грузоперевозок по СМП, но и обусловит развитие его инфраструктуры, судостроительной отрасли и сервисных отраслей, так или иначе связанных с транспортом.

Реализация (https://rg.ru/2019/07/25/sistema-arkticheskih-preferencij-budet-gotova-v-blizhajshie -nedeli.html) планов развития инфраструктуры СМП обеспечит круглогодичную работу арктической магистрали в период 2030-2035 годов и рост грузооборота СМП до 80 млн т к 2024 году с дальнейшим увеличением до 110-120 млн т к 2030 году и до 160 млн т к 2035 году.

Россия как страна, имеющая выход к Северному Ледовитому океану, не может обойтись без развитой транспортной системы Арктической зоны, в том числе без ледового флота. При грамотном подходе морские транспортные услуги могут превратиться в высокодоходную статью экспорта в Арктической зоне наряду с доходами от нефтегазовой отрасли.

Литература

1. «Росатом» станет совладельцем купивщей «Трансконтейнер» группь «Дело». Компании намерень создать новую контейнерную линию в Арктике. Бизнес, 03 декабря 2019. РБК. [Электронный ресурс]. Режим достуna: https://www.rbc.ru/business/03/12/2019/5de4ac8c9a7947d88b488164?utm_source=pushc, свободный. - Загл. с экрана.

2. «Стратегия пространственного развития РФ до 2025 года». Утверждена распоряжением Правительства РФ от 13.02.2019 № 207-р.

3. Башмакова Е. П. Опорные зоны как основа транспортной связанности Российской Арктики // Технологии построения когнитивных транспортных систем: материаль всероссийской научнопрактической конференции. СПб: ИПТ РАН. - 2018. - С. 203-209.

4. Козьменко С. Ю., Селин В. С. Современное оборонно-экономическое позиционирование России в арктических акваториях // Морской сборник. - 2016. - T. 2032. - № 7. - С. 38-43.

5. Комплексное освоение территории Российской Федераџии на основе транспортных пространственно-логистических коридоров. Актуальные проблемы реализации мегапроекта «Единая Евразия: ТЕПР ИЕТС» / Отв. ред. академик РАН В.В. Козлов, член-корреспондент РАН А. А. Макоско; Российская академия наук. - М.: Наука, 2019. - 463 с.

6. Комплексный план модернизации и расширения магистральной инфраструктуры на период до 2024 года. Утвержден Распоряжением Правительства Российской Федерации от 30 сентября 2018 года № 2101-p.

7. Минтранс описал Севморпуть до 2024 года. Газета «Коммерсантъ». - № 210 от 15.11.2018, cmp. 7. [Электронный ресурс]. Режим доступа: https://www.kommersant.ru/doc/3799581 (дата обращцения 17.11.2019), свободный. - Загл. с экрана.

8. План развития Северного морского пути (СМП) до 2035 года, разработан Госкорпорацией «Росатом» совместно Министерством Российской Федераиии по развитию Дальнего Востока и Арктики и внесен в Правительство РФ 25.11.2019 // Российская газета. Федеральный выпуск № 266 (8024).

9. Проект «Стратегии развития Арктической зоны РФ до 20135 года», разработан Министерством Российской Федерации по развитию Дальнего Востока и Арктики и Проектным офисом развития Арктики с привлечением регионов АЗРФ и внесен в Правительство РФ 01.12.2019. [Электронный ресурс]. Режим доступа: https://www.arctic2035.ru/ (дата обращения 04.12.2019), свободный. - Загл. с экрана. 
10. Северный морской путь. Досье. [Электронный ресурс]. Режим доступа: https://tass.ru/info/4999806 (дата обрашения 19.03.2019), свободный. - Загл. с экрана.

11. Севморпуть обойдется без «Лидера». Oil-Эксперт: 10 апреля 2019. [Электронный ресурс]. Режим docmyna: https://www.oilexp.ru/news/russia/sevmorput-obojdetsya-bez-lidera-novatehk-rasschityvaet-zapustitkruglogodichnuyu-navigaciyu-bez-sverkhmoshhnogo-ledokola/174992/ (дата обрашения 20 05.2019), свободный. - Загл. с экрана.

12. Селин В. С., Селин И. В. Тенденции развития арктических морских портов // Север и рынок: формирование экономического порядка. - 2018. - №1(57). - С. 55-66.

13. Ульченко М. В., Башмакова Е. П. Проблемы развития транспортной инфраструктуры в регионах Арктической зоны Российской Федерации // Экономика и управление: проблемы, решения. - 2018. - T. 7. - № 11. - C. 45-52.

14. Факторный анализ и прогноз грузопотоков Северного морского пути / Науч. ред. В. С. Селин, С. Ю. Козьменко. Апатиты: КНЦ РАН, 2015. - С. 335.

15. Шпак A. В. К вопросу о логистической координации товародвижения в арктических регионах России // Вестник КНЦ РАН. - 2011. - № 4. - C. 128-133.

\section{References:}

1. «Rosatom» stanet sovladel'cem kupivshej «Transkontejner» gruppy «Delo». Kompanii namereny sozdat' novuyu kontejnernuyu liniyu v Arktike. Biznes, 03 dekabrya 2019. RBK. [Elektronnyj resurs]. Rezhim dostupa: https://www.rbc.ru/business/03/12/2019/5de4ac8c9a7947d88b488164?utm_source=pushc, svobodnyj. - Zagl. s ekrana.

2. "Strategiya prostranstvennogo razvitiya $R F$ do 2025 goda». Utverzhdena rasporyazheniem Pravitel'stva RF ot 13.02.2019 № 207-r.

3. Bashmakova E. P. Opornye zony kak osnova transportnoj svyazannosti Rossijskoj Arktiki // Tekhnologii postroeniva kognitivnyh transportnyh sistem: materialy vserossijskoj nauchno-prakticheskoj konferencii. SPb: IPT RAN. - 2018. - S. 203-209.

4. Koz'menko S. YU., Selin V. S. Sovremennoe oboronno-ekonomicheskoe pozicionirovanie Rossii $v$ arkticheskih akvatoriyah // Morskoj sbornik. - 2016. - T. 2032. - № 7. - S. 38-43.

5. Kompleksnoe osvoenie territorii Rossijskoj Federacii na osnove transportnyh prostranstvenno-logisticheskih koridorov. Aktual'nye problemy realizacii megaproekta "Edinaya Evraziya: TEPR - IETS» / Otv. red. akademik RAN V.V. Kozlov, chlen-korrespondent RAN A. A. Makosko; Rossijskaya akademiya nauk. - M.: Nauka, 2019. $-463 s$.

6. Kompleksnyj plan modernizacii i rasshireniya magistral'noj infrastruktury na period do 2024 goda. Utverzhden Rasporyazheniem Pravitel'stva Rossijskoj Federacii ot 30 sentyabrya 2018 goda № 2101-r.

7. Mintrans opisal Sevmorput" do 2024 goda. Gazeta "Kommersant». - № 210 ot 15.11.2018, str. 7. [Elektronnyj resurs]. Rezhim dostupa: https://www.kommersant.ru/doc/3799581 (data obrashcheniya 17.11.2019), svobodnyj. - Zagl. s ekrana.

8. Plan razvitiva Severnogo morskogo puti (SMP) do 2035 goda, razrabotan Goskorporaciej «Rosatom» sovmestno Ministerstvom Rossijskoj Federacii po razvitiyu Dal'nego Vostoka i Arktiki $i$ vnesen v Pravitel'stvo RF 25.11.2019 // Rossijskaya gazeta. Federal'nyj vypusk № 266 (8024).

9. Proekt «Strategii razvitiya Arkticheskoj zony RF do 20135 goda», razrabotan Ministerstvom Rossijskoj Federacii po razvitivu Dal'nego Vostoka i Arktiki i Proektnym ofisom razvitiya Arktiki s privlecheniem regionov AZRF $i$ vnesen $v$ Pravitel'stvo $R F$ 01.12.2019. [Elektronnyj resurs]. Rezhim dostupa: https:// www.arctic2035.ru/ (data obrashcheniya 04.12.2019), svobodnyj. - Zagl. s ekrana.

10. Severnyj morskoj put'. Dos'e. [Elektronnyj resurs]. Rezhim dostupa: https://tass.ru/info/4999806 (data obrashcheniya 19.03.2019), svobodnyj. - Zagl. s ekrana.

11. Sevmorput' obojdetsya bez «Lidera». Oil-Ekspert: 10 aprelya 2019. [Elektronnyj resurs]. Rezhim dostupa. https://www.oilexp.ru/news/russia/sevmorput-obojdetsya-bez-lidera-novatehk-rasschityvaet-zapustit-

kruglogodichnuyu-navigaciyu-bez-sverkhmoshhnogo-ledokola/174992/ (data obrashcheniya 20 05.2019), svobodnyj. - Zagl. s ekrana.

12. Selin V.S., Selin I. V. Tendencii razvitiya arkticheskih morskih portov // Sever i rynok: formirovanie ekonomicheskogo poryadka. - 2018. - №1(57). - S. 55-66.

13. Ul'chenko M. V., Bashmakova E. P. Problemy razvitiya transportnoj infrastruktury v regionah Arkticheskoj zony Rossijskoj Federacii // Ekonomika i upravlenie: problemy, resheniya. - 2018. - T. 7. - № 11. - S. 45-52.

14. Faktornyj analiz i prognoz gruzopotokov Severnogo morskogo puti / Nauch. red. V. S. Selin, S. YU. Koz'menko. Apatity: KNC RAN, 2015. - S. 335.

15. SHpak A. V. K voprosu o logisticheskoj koordinacii tovarodvizheniya v arkticheskih regionah Rossii // Vestnik KNC RAN. - 2011. - № 4. - S. 128-133. 